\title{
SPATIAL VARIABILITY OF THE SATURATED HYDRAULIC CONDUCTIVITY OF SOIL IN COCOA FARMING IN RECÔNCAVO BAIANO ${ }^{1}$
}

\author{
GERLANGE SOARES DA SILVA ${ }^{2 *}$, JUCICLÉIA SOARES DA SILVA ${ }^{3}$, FRANCISCO ADRIANO DE CARVALHO \\ PEREIRA $^{2}$, RODRIGO ALMEIDA SANTANA ${ }^{4}$, RAFAEL SILVA FIRMO ${ }^{4}$, OSWALDO PALMA LOPES SOBRINHO
}

\begin{abstract}
Irrigated cocoa cultivation opened the way for production in Coastal Tablelands soils. However, in this region, the cohesive layer formed near the surface can be a limiting factor for production. The knowledge of physical soil water attributes enables the efficient irrigation management of cohesive soils. This study characterized and modeled the spatial variability of saturated hydraulic conductivity $\left(\mathrm{K}_{0}\right)$ in a Distrocoeso Oxisoil of the Recôncavo Baiano Coastal Tablelands. The soil sampling was performed as undeformed structures from 50 spaced points in an 8.0 to $8.0 \mathrm{~m}$ area, at three different depths in the experimental area of the Federal University of Bahia Recôncavo in the Cruz das Almas-BA cultivated with cocoa (' $\mathrm{CCN} 51$ '). In the laboratory, $\mathrm{K}_{0}$ was determined by permeameter method constant load, and the pore size distribution was determined using the voltage table and the soil density (Ds). Data were analyzed using descriptive statistics and geostatistics. On average, the $\mathrm{K}_{0}$ values were $40.41,26.49$, and $37.82 \mathrm{~mm}^{-1} \mathrm{~h}^{-1}$ at the depths from $0.0-0.15 \mathrm{~m}$, $0.15-0.30$, and $0.30-0.45 \mathrm{~m}$. The Gaussian model was the best fit to the $\mathrm{K}_{0}$ data set. For soil class, the $\mathrm{K}_{0}$ showed a strong spatial dependence due to their relationship with the physical properties of the soil, its use, and handling. Since an important attribute for the delimitation of homogeneous areas for specific site management purposes as well be considered.
\end{abstract}

Keywords: Theobroma cacao L. Precision agriculture. Geostatistics. Soil water physical attributes.

\section{VARIABILIDADE ESPACIAL DA CONDUTIVIDADE HIDRÁULICA SATURADA DO SOLO SOB CULTIVO DE CACAU NO RECÔNCAVO BAIANO}

RESUMO - O cultivo de cacau irrigado abriu espaço para a produção em solos de Tabuleiros Costeiros. Porém, nesta região, a camada coesa formada próxima da superfície, pode ser um fator limitante para sua produção. O conhecimento dos atributos físico-hídricos do solo possibilitará um manejo eficiente da irrigação em solos coesos. Com isso, objetivou-se caracterizar e modelar a variabilidade espacial da condutividade hidráulica saturada em Latossolo Amarelo Distrocoeso dos Tabuleiros Costeiros do Recôncavo Baiano. A amostragem de solo na estrutura indeformada foi realizada em 50 pontos espaçados de 8,0 em $8,0 \mathrm{~m}$, em três diferentes profundidades na área experimental da Universidade Federal do Recôncavo da Bahia, em Cruz das Almas - BA, cultivada com cacau CCN 51. Determinou-se em laboratório a $\mathrm{K}_{0}$ utilizando permeâmetro de carga constante, distribuição de poros utilizando mesa de tensão e a densidade do solo. Realizou-se análises descritiva e de geoestatística. Em média os valores da $\mathrm{K}_{0}$ foram 40,41 $\mathrm{mm} \mathrm{h}^{-1}, 26,49 \mathrm{~mm} \mathrm{~h}^{-1}$ e $37,82 \mathrm{~mm} \mathrm{~h}^{-1}$ nas profundidades $0,0-0,15 \mathrm{~m}, 0,15-0,30 \mathrm{~m}$ e 0,30-0,45 $\mathrm{m}$. O modelo gaussiano foi o que melhor se ajustou ao conjunto de dados da $\mathrm{K}_{0}$. Para a classe de solo avaliada, a $\mathrm{K}_{0}$ apresentou uma forte dependência espacial devido a sua relação com as propriedades físicas do solo, seu uso e manejo. Podendo assim, ser considerado um importante atributo para a delimitação de zonas homogêneas para fins de manejo sítio específicos.

Palavras-chave: Theobroma cacao L. Agricultura de precisão. Geoestatística. Atributos físico-hídricos do solo.

\footnotetext{
"Corresponding author

${ }^{1}$ Received for publication in $12 / 20 / 2018$; accepted in $07 / 10 / 2019$

Extracted from the first author's doctoral thesis.

${ }^{2}$ Postgraduate Program in Agricultural Engineering, Nucleus of Water and Soil Engineering, Universidade Federal do Recôncavo da Bahia, Cruz das Almas, BA, Brazil; gerlangesoares@hotmail.com - ORCID: 0000-0002-0254-2159, fadriano64@gmail.com - ORCID:0000-00023528-3261.

${ }^{3}$ Brazilian Agricultural Research Corporation - Embrapa Semi-Árido, Petrolina, PE, Brazil; jucicleiass@gmail.com - ORCID: 0000-00033409-0326.

${ }^{4}$ Center for Agrarian, Environmental and Biological Sciences, Universidade Federal do Recôncavo da Bahia, Cruz das Almas, BA, Brazil; rodrigoufrb@hotmail.com - ORCID: 0000-0002-2293-5996, rafasfirmino@gmail.com - ORCID: 0000-0001-5456-6446.

${ }^{5}$ Postgraduate Program in Agrarian Sciences, Agronomy, Instituto Federal de Educação, Ciência e Tecnologia Goiano, Rio Verde, GO, Brazil; oswaldo-palma@hotmail.com - ORCID: 0000-0002-4632-695X.
} 


\section{INTRODUCTION}

Agricultural productivity has intensified in geo-environmental units of the Coastal Tablelands due to its agricultural potential (LIRA et al., 2016) and the increase of irrigation techniques, which in turn also opens up space for the production of cocoa.

The soils of Coastal Tablelands, although well structured, cohesive layer present near their surface (0.30-0.70 m deep), which in turn can impair the production of various agricultural crops because of the high resistance soil penetration of roots when dry (RAMOS et al., 2013). In addition, this soil has temporarily waterlogged areas in the rainy season and dry areas in the dry season (LIMA et al., 2014).

The cohesive character, by directly influence the development of the root system, ends up limiting the extraction of water and nutrients by plants and reduces soil aeration (REZENDE et al., 2002). This can be a limiting factor for growing cocoa plants that concentrate the effective root system in the first 0.30 $\mathrm{m}$ deep soil layers and density on the surface that modifies the soil water dynamic may compromise the growth of plants.

Under agricultural cultivation, soils undergo many disturbances, mainly due to management practices, such as excavation and leveling, that cause soil disturbance, reduce pore size, increase the density, and consequently modify the $\mathrm{K}_{0}$ (MESQUITA; MORAES, 2004; ALMEIDA et al., 2017). Since the $K_{0}$ represents the ease with which the soil transmits water, it is influenced by the physical properties of the soil (GONÇALVES; LIBARDI, 2013).

Because of this, assessing the physical and water attributes, with respect to $\mathrm{K}_{0}$ under the cocoa cultivation in Coastal Tablelands soils, allows the prediction of how the growing influences soil properties, assisting farmers in making decisions that ensure the sustainability of natural resources and avoiding the degradation of potentially productive areas (STEFANOSKI et al., 2013).

The $\mathrm{K}_{0}$ can be determined under conditions of saturation and non-saturation of the soil, using laboratory and field methods; however, both have advantages and limitations. In the laboratory, there is more control of the measurement conditions; however, the representative area of the lower surface may not represent actual field conditions. Already in the field, disturbances promoted in the samples are reduced; however, the method is more complex, making it less feasible (MELO FILHO, 2002; IBRAHIM; ALIYU, 2016).

$\mathrm{K}_{0}$ is an attribute whose variation occurs in both time and space, making it difficult to determine. Therefore, using geostatistical techniques is necessary of and enables the determination of the spatial dependence (BOTTEGA et al., 2013; CORADO NETO et al., 2015). Furthermore, Cajazeira and Assis Junior (2011) reported that such information can reduce errors in the sampling process and the measurement results help in choosing management that is efficient for agricultural soils.

Thus, it becomes important to determining the $\mathrm{K}_{0}$ in soils under cocoa cultivation, as the results indicate whether the water available in the soil is enough to meet the water needs of the crop. In addition, the characterization of their essential variability is necessary to assist in the efficient management of soil and irrigation.

Given the above, the objective was to characterize and to model the spatial variability of saturated hydraulic conductivity Distrocoeso Oxisoils of the Coastal Tablelands under cacao culture in the Recôncavo Baiano.

\section{MATERIAL AND METHODS}

The experiment was conducted in the experimental area of the Graduate Program in Agricultural Engineering from the Federal University of Bahia Recôncavo (UFRB) in Cruz das Almas, Bahia, Brazil with geographic coordinates $12^{\circ} 40^{\prime} 12^{\prime \prime}$ South latitude and $39^{\circ} 6^{\prime} 7^{\prime}$ East longitude and an altitude of $220 \mathrm{~m}$.

According to the Köppen classification (KOTTEK et al., 2006), the climate is Am, which is warm moist tropical, with the drier months from September to March and the period of highest rain from April to August. The average annual rainfall is $1,170 \mathrm{~mm}$, with variations between 800 and 1,400 $\mathrm{mm}$. The average relative humidity is $80 \%$, the average annual temperature is around $24.5^{\circ} \mathrm{C}$, and the average wind speed is $3.1 \mathrm{~ms}^{-1}$ (GUIMARÃES et al., 2016).

The soil of the experimental area was classified as a Distrocoeso Oxisol (EMBRAPA, 2013), with a sandy loam texture, corresponding to a Typic Haplustox (SOIL SURVEY STAFF, 2014), located in the geo-environmental unit of Coastal Tablelands and having as typical features, cohesive layers.

The history of use and soil management in the experimental area in the last 10 years included the cultivation of cassava, followed by cattle grazing on grass pasture. In 2015, the soil was plowed and corrected for the cultivation of banana and paricá, and the intercropping with cocoa crop cultivation 'CCN 51' began in 2016 and lasted until June 2017. After thinning the banana plants, cocoa was the full solo across the central part of the area, with only two rows intercropped with paricá plants, one on the left end and the other on the right end.

The banana cutting was conducted during 2017, due to its regrowth, and all material was disposed of on the ground. Furthermore, cocoa and paricá leaves often fall on the ground and remained there; therefore, the soil surface now contains a 
significant layer of organic material that was formed during the development of crops, causing the soil restructuring.

The area was irrigated with micro sprinklers and a fertilizer application system to replenish essential nutrients to the crops. Fertilizer application was accomplished with a mixture of potassium chloride, monoammonium phosphate (MAP) and urea four times a year. In addition, weeding was done twice a year, and when necessary, pruning of cocoa plants and phytosanitary control was conducted.

Sampling for the evaluation of soil water physical attributes occurred on the entire cultivated area with cocoa culture at 50 different points with spacing of $8.0 \mathrm{~m}$ between the scores (Figure 1) georeferenced with the GPS GARMIN in UTM coordinates, Horizontal Datum WGS 84, Zone 22 South. There were 150 samples collected undisturbed at depths of $0.0-0.15,0.15-0.30$, and $0.30-0.45 \mathrm{~m}$ with the aid of volumetric rings $\left(98 \mathrm{~cm}^{3}\right)$.

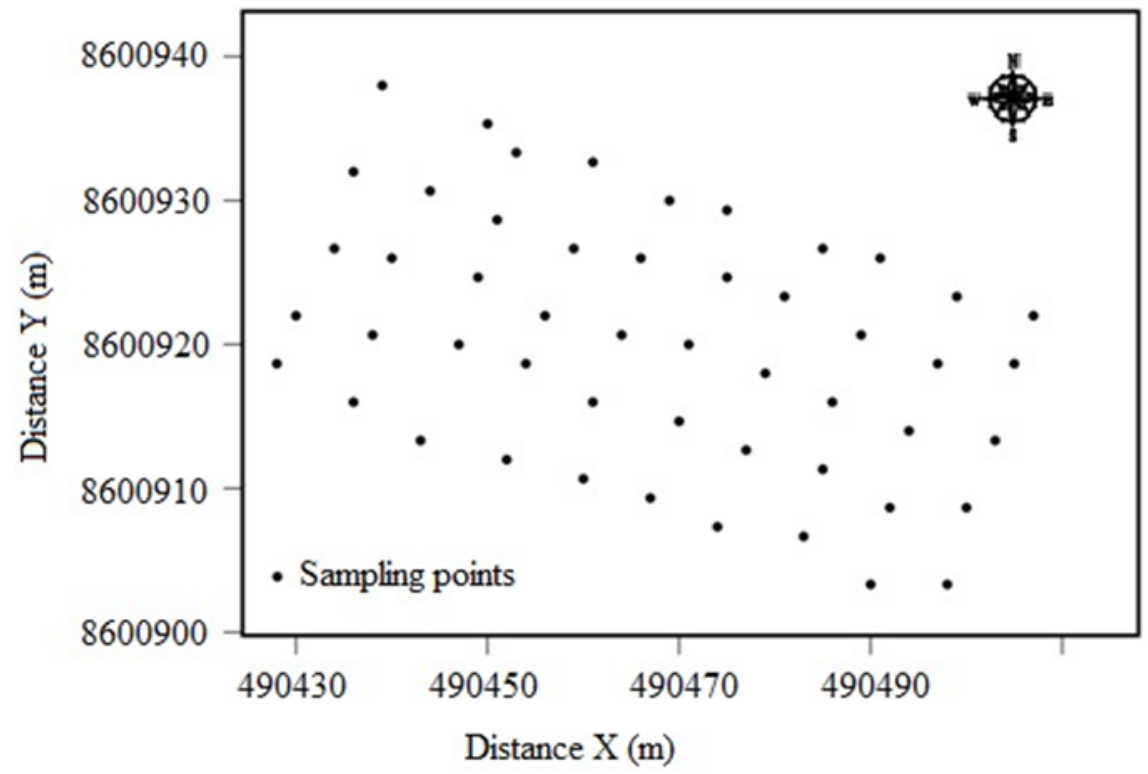

Figure 1. Distribution of sampling points in the study area.

Analyses for the determination of the attributes saturated hydraulic conductivity $\left(\mathrm{K}_{0}\right)$, soil density (Ds), macroporosity (Ma), micro (mi) and total porosity $(\mathrm{Pt})$ were performed in the laboratory. For determining the $\mathrm{K}_{0}$, the constant load permeameter was used (YOUNGS, 1991), with the percolated water volumes in the interval of one hour measured in a beaker and held seven consecutive measurements, thereby obtaining the average value of the readings. The $\mathrm{K}_{0}$ was calculated using Equation 1:

$$
K_{0}=\left(\frac{Q \times L}{A \times H \times t}\right)
$$

where $K_{0}$ is the hydraulic conductivity in $\mathrm{cm} \mathrm{h}^{-1}, \mathrm{Q}$ is the leachate volume in $\mathrm{cm}^{3}, \mathrm{~L}$ is the height of soil block in $\mathrm{cm}, \mathrm{H}$ is the height of unit in addition to the ground water column in $\mathrm{cm}, \mathrm{A}$ is the area in $\mathrm{cm}^{2}$ of the cylinder, and $t$ is the time in hours.

We used methods described by EMBRAPA (2017) for determining Ma, Mi, Pt, and Ds. For the distribution of pore sizes, we used the voltage table at $60 \mathrm{~cm}$ of water column. The volume of Ma was calculated as the difference between the measured mass of a saturated sample subjected to pressure of a $60 \mathrm{~cm}$ water column in relation to the volume of soil.
Mi was the difference between the masses of the samples measured after the voltage of a $60 \mathrm{~cm}$ water column and the samples dried at $105^{\circ} \mathrm{C}$. Pt represents the sum of Ma and Mi after the Ds was calculated by the difference between the masses of the samples after drying at $105^{\circ} \mathrm{C}$ and the volume of soil contained in the ring.

We conducted descriptive analyses of the data obtaining maximum values, minimums, means, medians, standard deviations, skewness coefficients, kurtosis values, and coefficients of variation. The normality of the data was tested using the Kolmogorov-Smirnov (KS) test with 1\% probability. For both analyses the Surfer 11.0 program was used (GOLDEN SOFTWARE, 2002), and it was used to generate spatial distribution maps of the attributes of the area.

The variability of $\mathrm{K}_{0}$ had its classification based on the coefficient of variation values $(\mathrm{CV})$ proposed by Warrick and Nielsen (1980), with values of low $(\mathrm{CV}<12 \%)$, medium (CV 12-62\%), and high $(\mathrm{CV}>62 \%)$.

After descriptive analysis verified the spatial dependence of the data using geostatistical techniques (ROBERTSON, 1998; VIEIRA, 2000), the adjustment of semivariograms occurred when semi variance $\gamma(\mathrm{h})$ was used to calculate the spatial 
correlation between local neighbors by Equation (2):

$$
\hat{\gamma}(h)=\frac{1}{2 N(h)} \sum_{i=1}^{N(h)}\left[Z\left(X_{i}\right)-Z\left(X_{i}+h\right)\right]^{2}
$$

where $N(H)$ is the number of experimental observations pairs of $\mathrm{Z}(\mathrm{x})$ and $\mathrm{Z}(\mathrm{x}+\mathrm{h})$ separated by a distance $h$.

The semivariograms were obtained and adjusted according to the criteria and procedures described by Vieira et al. (1983) using the program $\mathrm{GS}^{+}$. The set of mathematical models and define the parameters for semivariograms include: a) nugget $\left(\mathrm{C}_{0}\right)$, which is the value of $\gamma$ when $\left.\mathrm{h}=0 ; \mathrm{b}\right)$ extent of the spatial dependency (a), which is the distance where $\gamma(\mathrm{h})$ remains approximately constant, after increasing with the increase of $\mathrm{h}$; and c) threshold $\left(\mathrm{C}_{0}+\mathrm{C} 1\right)$, which is the value of $\gamma(\mathrm{h})$ from the scope and approaches the variance of the data.

The spatial variation of the $\mathrm{K}_{0}$ structure was represented by the Gaussian and exponential spherical mathematical models tested by means of equations (3), (4), and (5), respectively, after obtaining the semivariograms.

$$
\begin{aligned}
& \gamma(h)=C_{0}+C_{1}\left[1.5\left(\frac{h}{a}\right)-0.5\left(\frac{h}{a}\right)^{3}\right] 0<h \leq a \gamma(h)=C_{0}+C_{1} h>A \\
& \gamma(h)=C_{0}+C_{1}\left[1-\exp ^{\left.-\left(\frac{h^{2}}{a}\right)\right] h \neq 0}\right. \\
& \gamma(h)=C_{0}+C_{1}\left[1-\exp ^{-\left(\frac{h}{a}\right)}\right] h \neq 0
\end{aligned}
$$

A cross-validation of the semivariograms was carried out in the $\mathrm{GS}^{+}$program, which applied the least squares method for the settings of the models and used the following criteria for selecting models: i) the coefficient of determination $\left(\mathrm{R}^{2}\right)$, which recalling the regression analysis of concepts, is a ratio of the sum of squares due to the adjusted model and the total sum of squares (measures the variation in the data due to the adjusted model to the total variation of the data), and the closer the unit is the $\mathrm{R}^{2}$ value the better the adjusted model and ii) the waste sum of squares (RSS)-the lower this value is, the better the semivariogram model is. The $\mathrm{GS}^{+}$uses these results for the model selection, while using combinations of model parameters, and minimizing this sum of squares of waste.

The spatial dependence (GDE), determined according (CAMBARDELLA et al., 1994), is the proportion in percent of the nugget $\left(\mathrm{C}_{0}\right)$ in relation to the level $\left(\mathrm{C}_{0}+\mathrm{C}\right)$, and it was calculated according to $\left[\mathrm{C}_{0} /\left(\mathrm{C}_{0}+\mathrm{C}\right)\right]$. The spatial dependence was classified as strong when the ratio is GDE $\leq 25 \%$, moderate if GDE is $25-75 \%$ and weak GDE when $75-100 \%$, and classified as independent when the distribution is random, and the ratio is equal to $100 \%$.

\section{RESULTS AND DISCUSSION}

Further $\mathrm{K}_{0}$ values were observed in the layer $0.0-0.15 \mathrm{~m}$ (Table 1 ) in relation to the layers 0.15 0.30 and $0.30-0.45$, having an inversion in the distribution of pores and Ds.

The results observed for $\mathrm{K}_{0}$ as well as Ds and pore size distribution can be related to the class of soil, since Oxisoils are one of the predominant groups in Coastal Tablelands. These soils generally have horizontal cohesive layers near the soil surface, which may have formed both naturally and by the history of land use in the area. This land use includes the cultivation of plants and grazing animals, and the use of machines in the preparation of the land, thus decreasing the $\mathrm{K}_{0}$ and the volume of $\mathrm{Ma}$, as well as increasing Ds, and likely forming layers of compacted soils.

The results observed for $\mathrm{K}_{0}$ at certain depths may also be related to some factors that occur in the field and that were observed at the time of sampling. These include a high contribution of organic matter in the surface layer, one of the main components of the soil, which works to improve the structure influencing the hydraulic properties and translocation clay forming very hard layers at some depths, including at the sampled points, and the distribution of roots, which can also justify high values of Ds.

According to the relationship between the values of $\mathrm{K}_{0}$ and other attributes, there is an inversion, where the most compacted layer had the highest average and less compacted had a lower average $\mathrm{K}_{0}$. This is unlikely, since hydraulic conductivity is considered the quantification of the ground water flow and is directly related to the ability to drive the ground water, thus having the largest capacity at the least compacted soil. However, this paradoxical phenomenon can be explained by the factor that stands out for getting a good infiltration rate, which is the continuity of the pores in the soil, as stated by Costa et al. (2016). Lower porosity values can be found suitable, if due to good connectivity between the pores, this is not restrictive and there may be a good conduction of water. 
Table 1. Parameters of descriptive analysis of physical soil water attributes in cocoa cultivation in the Recôncavo Baiano, saturated hydraulic conductivity $\left(\mathrm{K}_{0}\right)$, soil density (Ds), macroporosity (Ma), micro (mi) and total porosity (Pt).

\begin{tabular}{|c|c|c|c|c|c|}
\hline & $\mathrm{K}_{0}$ & Ds & $\mathrm{Ma}$ & $\mathrm{Mi}$ & $\mathrm{Pt}$ \\
\hline & $\mathrm{mm} \mathrm{h}^{-1}$ & $\mathrm{~g} \mathrm{~cm}^{-3}$ & & $\mathrm{~m}^{3} \mathrm{~m}^{3}$ & \\
\hline \multicolumn{6}{|c|}{ Depth $0.0-0.15 \mathrm{~m}$} \\
\hline Average & 40.41 & 1.8 & 0.19 & 0.22 & 0.41 \\
\hline Median & 28.36 & 1.81 & 0.19 & 0.22 & 0.41 \\
\hline Maximum & 124.75 & 2.00 & 0.34 & 0.26 & 0.56 \\
\hline Minimum & 1.41 & 1.67 & 0.10 & 0.19 & 0.33 \\
\hline 1st Quartile & 17.59 & 1.77 & 0.14 & 0.21 & 0.38 \\
\hline 3rd Quartile & 53.49 & 1.87 & 0.23 & 0.23 & 0.43 \\
\hline Variance & 951.33 & 0.01 & 0.00 & 0.00 & 0.00 \\
\hline DP & 30.84 & 0.07 & 0.05 & 0.02 & 0.05 \\
\hline CV $(\%)$ & 76.33 & 4.11 & 28.42 & 7.85 & 11.64 \\
\hline Asymmetry & 1.16 & 0.19 & 0.47 & 0.06 & 0.74 \\
\hline Kurtosis & 0.67 & 0.25 & -0.40 & -0.56 & 0.42 \\
\hline $\mathrm{KS}$ & 0.23 & 0.23 & 0.23 & 0.23 & 0.23 \\
\hline \multicolumn{6}{|c|}{ Depth $0.15-0.30$} \\
\hline Average & 26.49 & 1.78 & 0.20 & 0.23 & 0.42 \\
\hline Median & 21.61 & 1.79 & 0.19 & 0.23 & 0.42 \\
\hline Maximum & 98.94 & 1.92 & 0.31 & 0.27 & 0.51 \\
\hline Minimum & 1.35 & 1.64 & 0.10 & 0.19 & 0.34 \\
\hline 1st Quartile & 12.75 & 1.75 & 0.15 & 0.21 & 0.39 \\
\hline 3rd Quartile & 35.11 & 1.83 & 0.24 & 0.24 & 0.46 \\
\hline Variance & 394.51 & 0.00 & 0.00 & 0.00 & 0.00 \\
\hline DP & 19.86 & 0.06 & 0.06 & 0.06 & 0.04 \\
\hline CV (\%) & 74.99 & 3.63 & 30.09 & 30.09 & 10.13 \\
\hline Asymmetry & 1.43 & -0.02 & 0.19 & -0.09 & 0.21 \\
\hline Kurtosis & 2.54 & -0.33 & -1.00 & -0.64 & -0.85 \\
\hline $\mathrm{KS}$ & 0.23 & 0.23 & 0.23 & 0.23 & 0.23 \\
\hline \multicolumn{6}{|c|}{ Depth $0.30-0.45 \mathrm{~m}$} \\
\hline Average & 37.82 & 1.74 & 0.20 & 0.24 & 0.43 \\
\hline Median & 29.47 & 1.74 & 0.21 & 0.23 & 0.43 \\
\hline Maximum & 110.09 & 2.00 & 0.30 & 0.30 & 0.52 \\
\hline Minimum & 2.27 & 1.26 & 0.08 & 0.19 & 0.37 \\
\hline 1st Quartile & 15.37 & 1.67 & 0.15 & 0.22 & 0.39 \\
\hline 3rd Quartile & 59.57 & 1.80 & 0.24 & 0.25 & 0.47 \\
\hline Variance & 811.49 & 0.01 & 0.00 & 0.00 & 0.00 \\
\hline DP & 28.49 & 0.12 & 0.06 & 0.02 & 0.05 \\
\hline CV (\%) & 75.32 & 6.80 & 29.95 & 9.88 & 10.91 \\
\hline Asymmetry & 0.89 & -1.05 & -0.08 & 0.84 & 0.22 \\
\hline Kurtosis & -0.002 & 4.74 & -1.05 & 0.68 & -1.19 \\
\hline $\mathrm{KS}$ & 0.23 & 0.23 & 0.23 & 0.23 & 0.23 \\
\hline
\end{tabular}

${ }^{*} \mathrm{CV}=$ Coefficient of Variation; DP Standard Deviation; KS $=$ KolmogorovSmirnov.

Rev. Caatinga, Mossoró, v. 32, n. 3, p. 786 - 794, jul. - set., 2019 
The observed results are in agreement with Almeida et al. (2017), who characterized the spatial variability of a saturated hydraulic conductivity soil Distrocoeso Oxisoilin the Municipality of Cruz das Almas, Bahia. They are also in agreement with Guimarães et al. (2016) who evaluated the spatial variability of soil physical attributes for Oxisoil areas, and Ultisol Inceptisols used for pasture. Kruger et al. (2016), when evaluating the spatial variability of physical soil water attributes in a small basin in southern Brazil, attributed this to several factors that occur at the soil surface. These included the presence of roots and cracking caused by animals (worms or ants and beetles), which in turn ended up influencing the values of $\mathrm{K}_{0}$, resulting in a tendency of overestimation.
The observed variation coefficients $\mathrm{K}_{0}: 76 \%$ at a depth of $0.0-0.15 \mathrm{~m}$ and $75 \%$ at depths of $0.15-$ $0.30 \mathrm{~m}$ and $0.30-0.45$ agree with most of studies that showed the heterogeneity of this attribute. Moreover, its variability ranked high according to the classification proposed by Warrick and Nielsen (1980) and may be related to the average variability observed Ma through their variation coefficients. This is one of the main attributes of the soil whose variability implies the variability of $\mathrm{K}_{0}$ at nearby locations and depths observed also through the semivariogram analysis parameters. These are shown in Table 2, which shows the degree of spatial dependence in the area in addition to the spatial maps of isolines where their distribution in the area is visible (Figure 2).

Table 2. Analysis parameters of semivariographic values of the saturated hydraulic conductivity under cocoa cultivation in Recôncavo Baiano.

\begin{tabular}{cccccccc}
\hline Depth & $\mathrm{C}_{0}$ & $\mathrm{C}_{0}+\mathrm{C} 1$ & $\mathrm{~A}_{0}(\mathrm{~m})$ & $\mathrm{IDE}(\%)$ & ranking & Model & $\mathrm{R}^{2}$ \\
\hline $0.0-0.15 \mathrm{~m}$ & - & - & - & - & - & EPP & - \\
$0,15-0.30 \mathrm{~m}$ & 209.3 & 418.7 & 13.33 & 21.71 & Strong & Gaussian & 0.78 \\
$0.30-0.45 \mathrm{~m}$ & 100.0 & 737.8 & 5.35 & 13.55 & Strong & Gaussian & 0.84 \\
\hline
\end{tabular}

*Effect nugget $\mathrm{C}_{0}, \mathrm{C}_{0}+\mathrm{C} 1$ porch, $\mathrm{A}_{0}$-range, IDE- spatial dependence index, coefficient of determination $\mathrm{R}^{2}$, EPP -Effect pure nugget.

For semivariogram data $\mathrm{K}_{0}$ of $0-0.15 \mathrm{~m}$ in no setting a theoretical model for having the attribute pure nugget effect (PPE), spatial dependence was not observed, and therefore their variability cannot be explained in because of its sampling distance (SOUZA et al., 2006) and as little as possible is the setting of a theoretical model of semivariogram. Already in the depths of $0.15-0.30$ and $0.30-0.45 \mathrm{~m}$ following the classification proposed by Cambardella et al. (1994), $\mathrm{K}_{0}$ showed strong spatial dependence presenting a better fit of the data set as a Gaussian model. The results indicate that, even in a small area, there can be heterogeneity of its attributes, ranging from local neighbors and depth. This emphasizes the importance of evaluating the variability of $\mathrm{K}_{0}$ using techniques such as geostatistics in which spatial maps (Figure 2) best represent the reality, making the information

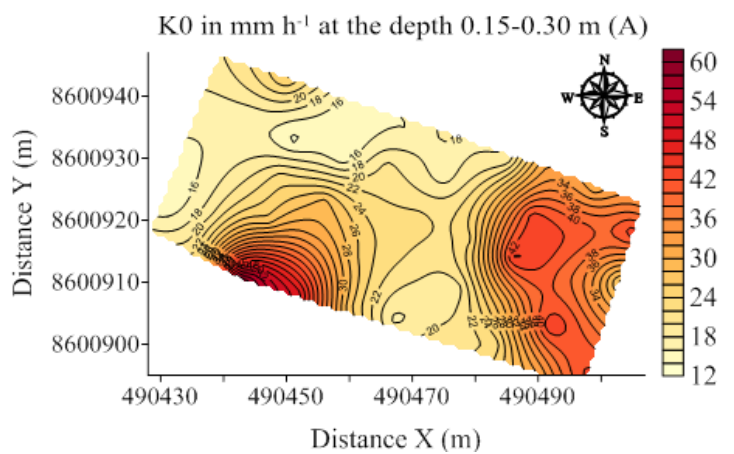

relevant to sustainable land use and its management practices, especially irrigation management.

Spatial variability was observed in that $\mathrm{K}_{0}$ in subsurface soil layers occurred in the same spatial pattern obtained from contour maps (Figure 2). Although the degree of spatial dependence for $\mathrm{K}_{0}$ classified according Cambardella et al. (1994) as strong for the of $0.15-0.30$ and $0.30-0.45 \mathrm{~m}$ layers in the last layer can be viewed in spatial maps, a more significant distribution of spatial dependence of the attribute. The results show that the estimated $\mathrm{K}_{0}$ to the surface considered for the delimitation of areas for homogeneous differential management purposes in the field, since the area has variation in nearby locations being observed a range of $5.33 \mathrm{~m}$ in the last layer and which is inside the sampling grid that was 8.0 to $8.0 \mathrm{~m}$.

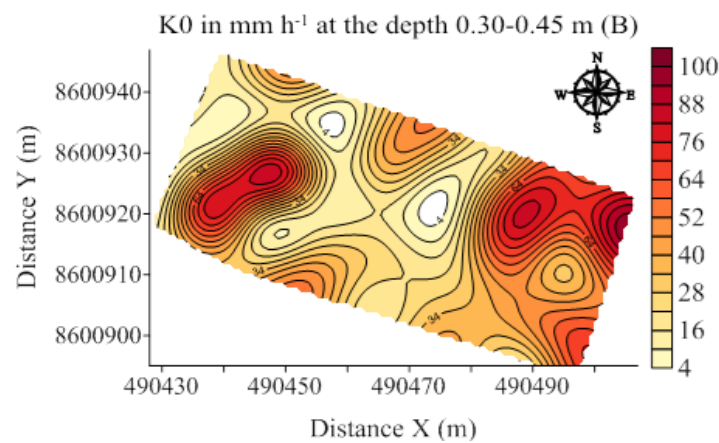

Figure 2. Map of isolines of the saturated hydraulic conductivity under cocoa cultivation in layers $0.15-0.30 \mathrm{~m}(\mathrm{~A})$ and $0.30-0.45 \mathrm{~m}(\mathrm{~B})$. 
Almeida et al. (2017), characterizing the spatial variability of $\mathrm{K}_{0}$ in a neighboring area with the same soil type, were also unable to detect spatial dependence of $\mathrm{K}_{0}$ in the first layer of soil evaluated. It is therefore recommended to reduce the spacing in the next sampling or use an irregular mesh with varying distances to detect the spatial variability. The results also corroborated with Guimarães et al. (2016), Kruger et al. (2016), and Marques et al. (2008), who observed spatial dependence for $\mathrm{K}_{0}$ at subsurface depths.

The distribution spatial of $\mathrm{K}_{0}$ can be attributed to intrinsic or extrinsic factors. In the first case, these are predominately factors related to soil formation (mineralogy, grain size), while the second case, these are more related to management practices and land use, such as agricultural use, animal grazing, and the use of machines and tools to turn the soil, which modifies its structure and consequently it's related attribute $\mathrm{K}_{0}$. Generally, a strong spatial dependence of soil properties is attributed to intrinsic factors and to extrinsic factors, a weak dependency (CAMBARDELLA et al., 1994; CARVALHO; TAKEDA; FREDDI, 2003).

Therefore, higher values $\mathrm{K}_{0}$ at $0.0-0.15 \mathrm{~m}$ in the layer are associated with the form of use of the area, which in turn promotes soil aggregation. However, in layers of $0.15-0.30$ and $0.30-0.45 \mathrm{~m}$, the changes in the physical properties of the soil may be related to the results, as shownby the strong spatial dependence on depth that did not occur on the surface. The results obtained were in accordance with Marques et al. (2008), who by analyzing the saturated hydraulic conductivity in a topo sequence with different vegetation types the Lower Amazon, found higher values of this attribute at the surface, citing that $\mathrm{K}_{0}$ is more sensitive to changes in the physical properties of the soil and the relief position than to changes in vegetation. Almeida et al. (2017) also obtained the same behavior for the soil water physical attributes of the soil for the superficial and subsurface layers, confirming the relationship between the saturated hydraulic conductivity and the other attributes of the soil.

\section{CONCLUSIONS}

The Gaussian model was the best fit for the $\mathrm{K}_{0}$ data set, which showed strong spatial dependence on the layers of $0.15-0.30$ and $0.30-0.45 \mathrm{~m}$, which was detected in the $0.0-0.15 \mathrm{~m}$ layer. The statistical analysis and geostatistics showed a high spatial variability for the attribute in the area and depth, considering for the delimitation of homogeneous areas for specific site for management purposes, and the soil class indicates that values were consistent with the physical properties of the soil, as well as its use and management.

\section{ACKNOWLEDGMENTS}

We wish to acknowledge the Foundation for the Bahia State Research (FAPESB) for granting a Doctoral Scholarship, the Higher Education Personnel Improvement Coordination (CAPES), for supporting research, the Postgraduate Program in Agricultural Engineering, and the laboratory technicians of Physical Analysis in the Postgraduate Program in Soils and Ecosystem Quality of the Federal University of Recôncavo Baiano.

\section{REFERENCES}

ALMEIDA, K. S. S. A. et al. Variabilidade espacial da condutividade hidráulica do solo saturado em Latossolo Amarelo Distrocoeso, no município de Cruz das Almas. Irriga, v. 22, n. 2, p. 259-274, 2017.

BOTTEGA, E. L. et al. Variabilidade espacial de atributos do solo em sistema de semeadura direta com rotação de culturas no cerrado brasileiro. Revista Ciência Agronômica, v. 44, n. 1, p. 1-9, 2013.

CAMBARDELLA, C. A. et al. Field-scale variability of soil proprieties in central Iowa soils. Soil Science Society of America Journal, v. 58, n. 5 , p. 1501-1511, 1994.

CARVALHO, M. P.; TAKEDA, E. Y.; FREDDI, O. S. Variabilidade espacial de atributos de um solo sob videira em Vitória Brasil (SP). Revista Brasileira de Ciência do Solo, v. 27, n. 4, p. 695-703, 2003.

CAJAZEIRA, J. P.; ASSIS JÚNIOR, R. N. Variabilidade espacial das frações primárias e agregados de um Argissolo no Estado do Ceará. Revista Ciência Agronômica, v. 42, n. 2, p. 258267,2011

CORADO NETO, F. C. et al. Variabilidade espacial dos agregados e carbono orgânico total em Neossolo Litólico Eutrófico no município de Gilbués, PI. Revista de Ciências Agrárias, v. 58, n. 1, p. 75-83, 2015 .

COSTA, C. D. O. et al. Produção e deposição de sedimentos em uma sub-bacia hidrográfica com solos suscetíveis à erosão. Irriga, v. 21, n. 2, p. 284 299, 2016

EMPRESA BRASILEIRA DE PESQUISA AGROPECUÁRIA - EMBRAPA. Centro Nacional de Pesquisa de Solos. Sistema brasileiro de classificação de solos. 3. ed. Rio de Janeiro, RJ: Embrapa - SPI, 2013. 353p. 
EMPRESA BRASILEIRA DE PESQUISA AGROPECUÁRIA - EMBRAPA. Manual de métodos de análise de solo. Livro técnico (INFOTECA-E). 3. ed. Brasília, DF: Embrapa, 2017. $573 p$.

GOLDEN SOFTWARE. Surfer 11.0 - user's guide. New York: Golden Software, 2002.

GONÇALVES, A. D. M. A.; LIBARDI, P. L. Análise da determinação da condutividade hidráulica do solo pelo método do perfil instantâneo. Revista Brasileira de Ciências do Solo, v. 37, n. 5, p. 11741184, 2013.

GUIMARÃES, M. J. M. et al. Balanço hídrico para diferentes regimes pluviométricos na região de Cruz das Almas-BA. Revista de Ciências Agrárias (Belém), v. 59, n. 3, p. 252-258, 2016.

GUIMARÃES, W. D. et al. Variabilidade espacial de atributos físicos de solos ocupados por pastagens. Revista Ciência Agronômica, v. 47, n. 2, p. 247$255,2016$.

IBRAHIM, M. M.; ALIYU, J. Comparison of methods for saturated hydraulic conductivity determination: field, laboratory and empirical measurements. British Journal of Applied Science \& Technology, v. 15, n. 3, p. 1-8, 2016.

KOTTEK, M. et al. World Map of the KöppenGeiger climate classification updated, Meteorologische Zeitschrift, 2006, p. 259-263.

KRUGER, B. G. et al. Spatial variability of soil physical and hydraulic properties in the southern Brazil small watershed. African Journal of Agricultural Research, v. 11, n. 49, p. 5036-5042, 2016.

LIMA, J. R. S. et al. Atributos físico-hídricos de um Latossolo Amarelo cultivado e sob mata nativa no Brejo Paraibano. Revista Brasileira de Ciências Agrárias, v. 9, n. 4, p. 599-605, 2014.

LIRA, R. A. et al. Uso agrícola e atributos físicohídricos de solo coeso. Revista Brasileira de Geografia Física, v. 9, n. 7, p. 2277-2289, 2016.

MARQUES, J. D. O. et al. Avaliação da condutividade hidráulica do solo saturada utilizando dois métodos de laboratório numa topossequência com diferentes coberturas vegetais no Baixo Amazonas. Acta Amazonas, v. 38, n. 2, p. 193-206, 2008.
MELO FILHO, J. F. Variabilidade dos parâmetros da equação da condutividade hidráulica em função da umidade de um Latossolo sob condições de campo. 2002. 145 p. Tese (Doutorado em Agronomia, Área de Concentração: Solos e Nutrição de Plantas) - Escola Superior de Agricultura Luiz de Queiroz, Piracicaba, 2002.

MESQUITA, M. G. B. F.; MORAES, S. O. A dependência entre a condutividade hidráulica saturada e atributos físicos do solo. Ciência Rural, v. 34, n. 3, p. 963-969, 2004.

RAMOS, B. Z. et al. Avaliação dos atributos físicohídricos em um Latossolo Vermelho distroférrico sob diferentes sistemas de manejo-Lavras/Minas Gerais/Brasil. Revista de Ciências Agrárias, v. 36, n. 3, p. 440-446, 2013.

REZENDE, J. O. et al. Citricultura nos solos coesos dos Tabuleiros Costeiros; análise e sugestões. Salvador, Secretaria da Agricultura, Irrigação e Reforma Agrária, 2002. 97p. (Série Estudos Agrícolas, 3).

ROBERTSON, G. P. GS ${ }^{+}$geostatistics for the environmental sciences: $\mathrm{GS}^{+}$user's guide. Plainwell: Gamma Design Software, 1998, 152 p.

SOUZA, Z. M. et al. Dependência espacial da resistência do solo à penetração e teor de água do solo sob cultivo de cana-de-açúcar. Ciência Rural, v. 36, n. 1, p. 128-134, 2006.

SOIL SURVEY STAFF. Keys to Soil Taxonomy. 12. ed. USDA-Natural Resources Conservation Service, Washington, DC. 372 p. 2014.

STEFANOSKI, D. C. et al. Uso e manejo do solo e seus impactos sobre a qualidade física. Revista Brasileira de Engenharia Agrícola e Ambiental, v. 17, n. 12, p. 1301-1309, 2013.

VIEIRA, S. R. et al. Geostatistical theory and application to variability of some agronomical properties. Hilgardia, v. 51, n. 3, p. 1-75, 1983.

VIEIRA, S. R. Geoestatística em estudos de variabilidade espacial do solo. In: NOVAIS, R. F.; ALVAREZ, V. H.; SCHAEFER, C. E. G. R. (Eds.). Tópicos em ciência do solo. Viçosa: Sociedade Brasileira de Ciência do Solo, 2000. v. 1, 352p.

WARRICK, A. W.; NIELSEN, D. R. Spatial variability of soil physical properties in the field. In: HILLEL, D. (Ed.). Applications of soil physics. New York: Academic, 1980. cap. 2, p. 319-344. 
YOUNGS, E. G. Hydraulic conductivity of saturated soils. In: SMITH, K. A.; MULLINS, C. E. (Ed.).

Soil analysis: physical methods. New York:

Marcel Dekker, 1991. cap. 4, p. 161-207. 